\title{
Thermal Stress Effects on Gene Expression and Phagocytosis in the Com- mon Carp (Cyprinus Carpio): a Better Understanding of the Summer 2001 st. Lawrence River Fish Kill
}

\author{
Valérie Ouellet ${ }^{1,2, *}$, Fabien Pierron ${ }^{1}$, Marc Mingelbier ${ }^{3}$, Michel Fournier ${ }^{4}$, Marlène Fournier ${ }^{4}$ and \\ Patrice Couture ${ }^{1}$ \\ ${ }^{1}$ INRS - Centre Eau Terre Environnement, 490 de la Couronne, Québec, G1K 9A9, Canada \\ ${ }^{2}$ Canadian Rivers Institute, University of New Brunswick, Fredericton, N. B. Canada \\ ${ }^{3}$ Ministère des ressources naturelles et de la faune du Québec, Service de la Faune Aquatique, 880 chemin Sainte-Foy, \\ $2^{e}$ étage, Québec, G1S 4X4, Canada \\ ${ }^{4}$ INRS - Institut Armand Frappier, 531 boul. des Prairies, Laval, H7V 1B7, Canada
}

\begin{abstract}
In summer 2001, the St. Lawrence River (Québec, Canada) experienced perhaps the largest massive fish kill of its history, with more than 25000 carp (Cyprinus carpio) found dead. This experiment therefore investigated the effects of heat stress on the gene transcription level of heat shock protein 70 , cytochrome c oxidase and mitochondrial superoxide dismutase expression as well as on phagocytosis of kidney cell suspensions and animal behaviour. Our study suggests that in summer 2001, elevated water temperatures could have contributed to the fish kill through immunosuppression during an already stressful spawning period.
\end{abstract}

Keywords: Fish kill, Gene expression, Phagocytosis, St. lawrence river, Thermal stress.

\section{INTRODUCTION}

Water temperature is known to be a major factor affecting habitat suitability of fish [1-4]. Alterations in thermal regime of a river can have consequences on all aspects of fish life including reproduction, survival, feeding, growth, habitat selection, migration, intra- and inter-specific competition [1, 2, 5-9]. By affecting so strongly habitat suitability of fish, water temperature has the potential to be a direct or an indirect factor provoking important massive fish kill events.

In summer 2001, the St. Lawrence River experienced a massive fish kill event [8]. According to the literature, this event may have been the most important fish kill reported in the Great Lakes and St. Lawrence River history. Although the exact number of dead fish remains unknown, more than 25000 common carp (Cyprinus carpio) were found dead, as well as some specimens of Catostomidae, Anguillidae, Acipenseridae, Ictaluridae, Esocidae, Percidae, and Centrarchidae. The mortality occurred in the St. Lawrence River between Montréal and Québec City (Fig. 1), from June $28^{\text {th }}$ until July $13^{\text {th }}$. It has been reported that the ultimate cause of mortality was infections by Aeromonas hydrophila and Flavobacterium $s p$. [10]. Those bacteria are commonly found in freshwater ecosystems and are not harmful to healthy fish.

*Address correspondence to this author at the INRS - Centre Eau Terre Environnement, 490 de la Couronne, Québec, G1K 9A9, Canada;

Tel: 418-809-7953; Fax: 418-654-2600; E-mail: valeria.ouellet@gmail.com
Exceptionally high water temperatures were measured in the period during which carp were spawning and were therefore already affected by energy expenses for reproduction. Water temperatures in the river reached $34^{\circ} \mathrm{C}$ in some points [8]. Frequency analyses made on water temperature series showed that daily maximum water temperature around Montréal and Québec City was abnormally high (return period, ie. the probability that the event will be equalled or exceeded, of 47 years) relative to other years [12]. Air temperatures were also abnormally elevated around Montréal, with a return period of 22 years. During the same period, the St. Lawrence River also experienced extremely low water levels, for which return periods in the Montréal area were around 30 years; with a maximum of 67 years in the Québec City area.

The main objective of this study was to test experimentally the hypothesis that elevated temperatures such as those measured during summer 2001 in the St. Lawrence River led to immunosupression triggering massive mortality of indigenous carp. We also examined whether heat stress affected the transcription level of genes encoding for proteins involved in protecting proteins against heat denaturation (heat shock protein $70, h s p 70$ ), in the fight against oxidative stress (mitochondrial superoxide dismutase, $\operatorname{sod} 2$ ) and in aerobic capacities (cytochrome c oxidase subunit 1, ccol). Fish behaviour was also monitored to investigate if the high temperatures used were stressful for the common carp. 


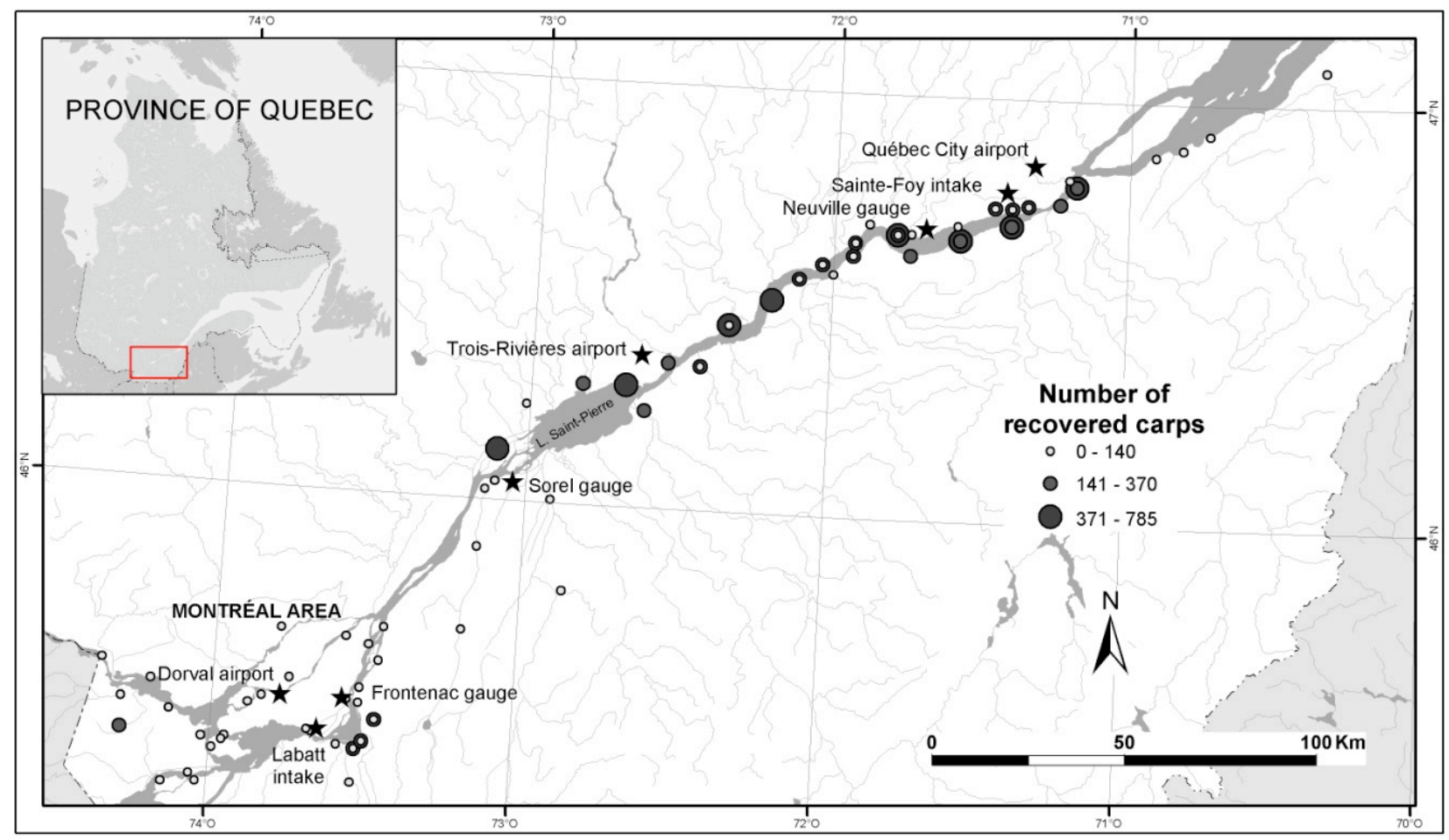

Fig. (1). Study area: Locations where dead fish were recovered during the fish kill of 2001 in the St. Lawrence River. Stars indicate the location of measurement stations used for the frequency analyses [12].

\section{MATERIALS AND METHODS}

\subsection{Fish Sampling and Laboratory Exposure to Heat Stress}

There are no official records of fish size, gender or stage of sexual maturity for the fish kill of 2001. For this experiment, carp were captured in June with gill nets in two different bays of the Lake St. Pierre archipelago (see Fig. (1) for the location of the lake) were they occur prior to the spawning period. Once deployed, nets were visited continuously to avoid wounding the fish. After capture, fish were kept into an oxygenated transportation container until the end of the day. An effort was made to capture female fish that weighed more than $11 \mathrm{Kg}$ (around the same weight as those observed dead in 2001). Fish were transported by van using an oxygenated transportation container from Lake St. Pierre to Québec City to be kept in a controlled environment at the LARSA Laval University facilities, where all physicochemical parameters could be monitored and adjusted as the experiment required. Photoperiod reproduced the natural cycle at the site of fish capture and the tanks were halfcovered with a transparent lid, and half with an opaque lid to limit animal stress. Fish were kept into two separate $3000 \mathrm{~L}$ circular tanks. In the first one (Control Unit, CU), fish ( $\mathrm{n}=5$ ) were kept at the same temperature as when they were fished $\left(18^{\circ} \mathrm{C}\right)$. In the second tank (Heat Treatment Unit, HU) $(n=4)$, water temperature was gradually raised from $18^{\circ} \mathrm{C}$ to $34.8^{\circ} \mathrm{C}$ at the rate of one degree per day. Oxygen was kept at saturation and expected to decrease in concentration as water temperature increased. Before the experiment, a five-day acclimation period was necessary to let fish adapt to their new environment. There were several attempts to feed the fish during the acclimation period but since they were almost ready to spawn, there were not eating and the feeding was stopped. Once their behaviour was considered to have returned to normal, the experiment began for 17 days during which fish behaviour was observed daily. The maximal temperature was set to $34.8^{\circ} \mathrm{C}$. At this temperature fish began to show different behavioural patterns (see Section 3.4).

At the end of the exposures, fish were sacrificed by a blow to the head. Gills were dissected and stored at $-80^{\circ} \mathrm{C}$ for gene transcription analysis. Head kidneys were removed under sterile conditions and homogenised with stainless steel mesh in tissue culture medium RPMI 1640 (Sigma, On, Canada) supplemented with heparin $(10 \mathrm{U} / \mathrm{ml})(\mathrm{CDMV}, \mathrm{Qc}$, Canada), HEPES (10mM) (Sigma, On, Canada), penicillin $(100 \mathrm{U} / \mathrm{ml}) /$ Streptomycin $(100 \mathrm{mg} / \mathrm{ml})$ (Sigma, On, Canada), $10 \%$ heat-inactivated Foetal Bovine Serum (FBS) (Sigma, On, Canada), at $\mathrm{pH}$ 7.2. The cells were isolated by centrifugation on Lympholyte-M (density= 1.085) (Cedarlane, On, Canada) at $600 \mathrm{~g}$ for $20 \mathrm{~min}$ at room temperature. Cells were collected from the Lympholyte-M interface and washed two times in PBS (Sigma, On, Canada) and resuspended in RPMIc containing $10 \%$ FBS, $100 \mathrm{U} / \mathrm{ml}$ penicillin, $100 \mathrm{mg} / \mathrm{ml}$ streptomycin and $10 \mathrm{mM}$ HEPES. Viability of macrophages was assessed using trypan blue dye exclusion under a microscope with a hemacytometer.

\subsection{Quantitative rt-PCR}

For each gene, specific primers were determined (Table 1) using the Primer Express ${ }^{\circledR}$ software (Applied Biosystems). Total RNA was extracted from $60 \mathrm{mg}$ of gills using the PureLink $^{\text {TM }}$ Micro-to-Midi ${ }^{\text {TM }}$ Total RNA Purification System (Invitrogen). During this step, samples were submitted to DNAse I treatment, according to manufacturer's instructions. For each sample, RNA quality was evaluated by elec- 
Table 1. Sequences of Specific Primer Pairs used in Quantitative Real-time PCR Analyses

\begin{tabular}{|c|c|c|}
\hline Gene & Function & Specific Primers (5'-3') \\
\hline$\beta$-actin & Internal standard & $\begin{array}{l}{ }^{a} G G G T A T G G A G T C T T G C G G T A \\
{ }^{\mathrm{b}} \text { ACAGGTCCTTACGGATGTCG }\end{array}$ \\
\hline cco-1 & Mitochondrial respiratory chain & $\begin{array}{c}{ }^{a} C A C G C A G G A G C A T C A G T A G A \\
{ }^{\mathrm{b}} \text { GATCAGACGAACAGGGGTGT }\end{array}$ \\
\hline hsp-70 & Protein folding and protection & $\begin{array}{l}{ }^{a} T C A T G G G A G A C A C A T C T G G A \\
{ }^{\mathrm{b}} \text { AGGTCTGGGTCTGTTTGGTG }\end{array}$ \\
\hline sod-2 & Detoxification /oxidative stress & $\begin{array}{l}{ }^{\mathrm{a}} \text { TTATGCAGCTTCACCACAGC } \\
{ }^{\mathrm{b}} \text { TATGGCCACCACCGTTAAAT }\end{array}$ \\
\hline
\end{tabular}

${ }^{\mathrm{a}}$ forward primer, ${ }^{\mathrm{b}}$ reverse primer

trophoresis on a $1 \%$ agarose gel and RNA concentrations as well as purity were determined by spectrophotometry (NanonoDrop 2000, Thermo Scientific). First-strand cDNA was then synthesized from $1 \mu \mathrm{g}$ of total RNA using the High Capacity RNA-to-cDNA Kit (Applied Biosystems), according to the manufacturer's instructions. Following the reverse transcriptase reaction, cDNA was diluted 100-fold. Realtime PCR reactions were then performed in duplicate in a ABI PRISM ${ }^{\circledR} 7000$ Sequence Detection System (Applied Biosystems) following the manufacturer's instructions $\left(50^{\circ} \mathrm{C}\right.$ for $2 \mathrm{~min}, 95^{\circ} \mathrm{C}$ for $10 \mathrm{~min}$, followed by 40 cycles of $95^{\circ} \mathrm{C}$ for $15 \mathrm{~s}$ and $60^{\circ} \mathrm{C}$ for $1 \mathrm{~min}$ ). Each $25 \mu \mathrm{L}$ reaction contained $12.5 \mu \mathrm{L}$ Sybr Green Universal PCR master mix (Applied Biosystems), $5 \mu \mathrm{L}$ template and the specific primer pairs at a final concentration of $300 \mathrm{nM}$ each. Amplification efficiencies for all primer sets were calculated and all values proved to be sufficient to allow direct comparison of amplification plots according to the $\Delta \mathrm{Ct}$ method [11]. Relative quantification of gene expression was achieved by concurrent amplification of the $\beta$-actin endogenous control. In this view, during our experiment, total RNAs were quantified and $1 \mu \mathrm{g}$ were used to be reverse-transcribed. During the subsequent qPCR amplifications, the output cycle corresponding to the $\beta$-actin was investigated. This output was always obtained around the same cycle for control (output cycle $=17.2 \pm 0.1$, mean \pm $\mathrm{SD}, \mathrm{n}=5$ ) and heat-treated (output cycle $=17.4 \pm 0.3$, mean $\pm \mathrm{SD}, \mathrm{n}=4$ ) individuals, demonstrating the relevance of the $\beta$-actin as reference gene in our conditions.

\subsection{Phagocytosis}

Phagocytosis assays were done following the procedure described in Brousseau et al. [13]. Briefly, a duplicate of 500 $\mu 1$ of each cellular suspension was adjusted to $1 \times 10^{6} \mathrm{cells} / \mathrm{ml}$ in $5 \mathrm{ml}$ polypropylene round bottom tubes (Sarstedt, USA) (non adherent tubes). Fluorescent latex beads $(\mathrm{d}=1.72 \mu \mathrm{m})$ (Polysciences, PA, USA) were added to the cell suspensions to give a 100:1 (bead:cell) ratio. Tubes were covered with paraffin and protected against light. Cells and beads were incubated at $15^{\circ} \mathrm{C}$ for $18 \mathrm{~h}$. Following incubation, cellular suspensions were layered separately over $4 \mathrm{ml}$ of RPMI supplemented with $3 \%$ of bovine serum albumin (BSA) (Sigma, On, Canada) and $10 \%$ of FBS. Elimination of free beads was performed by centrifugation at $150 \mathrm{~g}$ for $8 \mathrm{~min}$ at $4^{\circ} \mathrm{C}$. Cell pellets were then resuspended in $0.5 \mathrm{ml}$ of $0.5 \%$ formalde- hyde (Sigma, On, Canada) and $0.2 \%$ sodium azide (Sigma, On, Canada) diluted in BDFacsflow ${ }^{\mathrm{TM}}$ (Becton Dickinson, CA, USA). Cells were analysed by flow cytometry and 10000 events were recorded. Analyses were done using two biomarkers defined as the percentage of phagocytes (macrophages containing one bead or more: M1) and then as the phagocytosis efficiency (macrophages containing three beads or more: M2).

\subsection{Behavioural Observations}

Fish holding tanks were located in an isolated room which was only accessed for behavioural observations, carried out in thirty-minute periods at three different times of the day (7h00, 12h45 and 20h00), and for five minutes of daily maintenance. Fish behaviour (swimming, air breathing and resting time) was observed and recorded every day of the experiment, as well as during acclimation.

\subsection{Statistical Analyses}

Statistical analyses were made using Kruskal-Wallis nonparametric analysis of variance, which is suitable for low sample size as in this study. Statistical significance was set at 0.05. Analyses were performed with Statistica V6.0.

\section{RESULTS AND DISCUSSION}

\subsection{Capture and Husbandry of Large Common Carp}

This study was intrinsically highly challenging to carry out, given the experimental context. In order to investigate the causes of the massive fish die off in the summer of 2001 during a heat spell in the St. Lawrence River, we attempted to reproduce in the laboratory the field situation that occurred in situ. To this end, we had to capture, transport and maintain in the laboratory very large fish. Larger fish are much more difficult to capture and handle without injury and stress than smaller fish and even the large holding tanks used represented a confined and stressful environment for these wild fish. Under such challenging experimental conditions added to the already stressful natural conditions faced by these fish during breeding, six attempts were required to control the outbreak of fungal and bacterial infections and successfully maintain these large fish for long enough to complete the heat exposures. The resulting low sample size in this study ( $\mathrm{n}=5$ or 4 for $\mathrm{CU}$ and HU, respectively) somewhat 

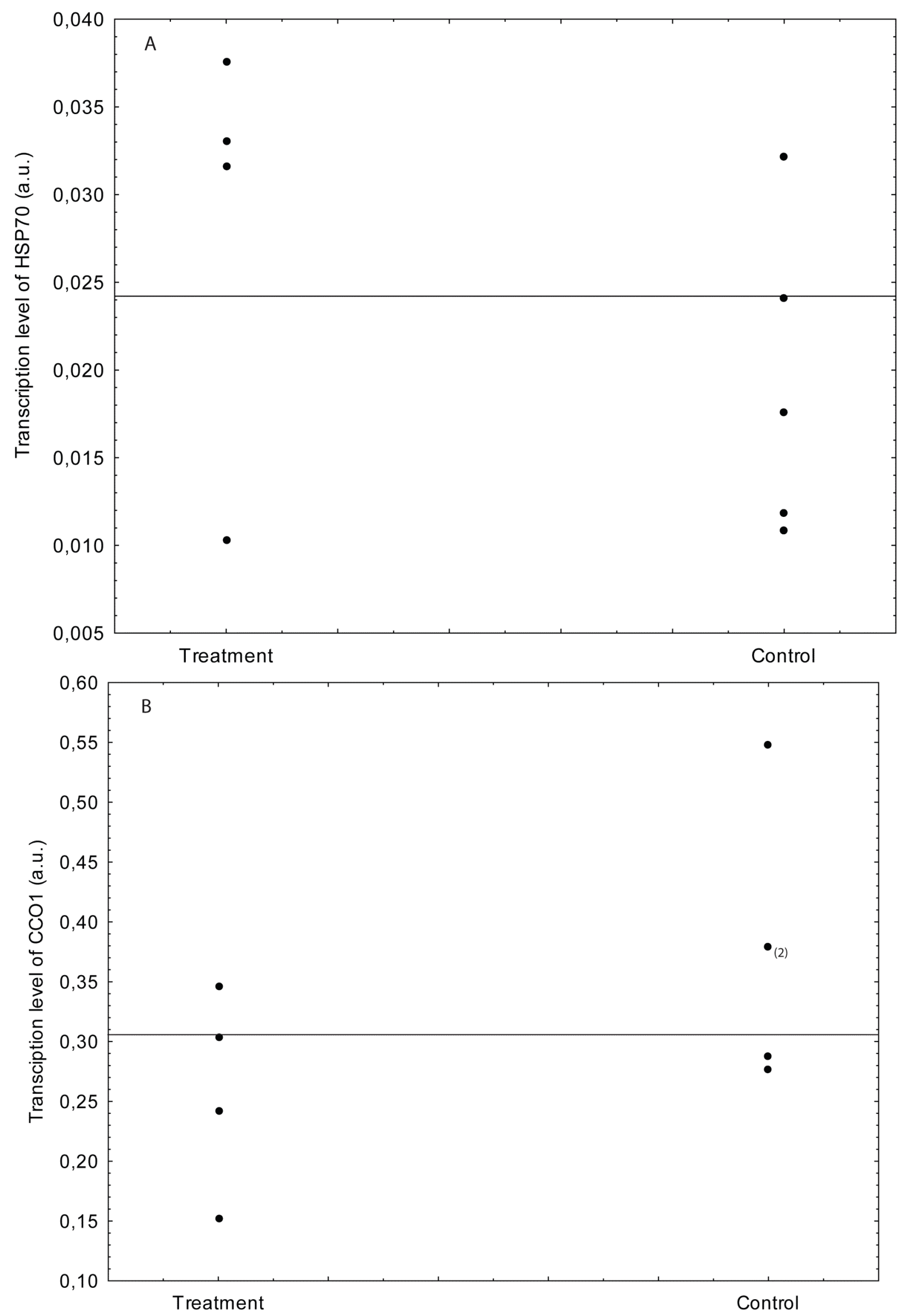
Fig. (2). Contd...

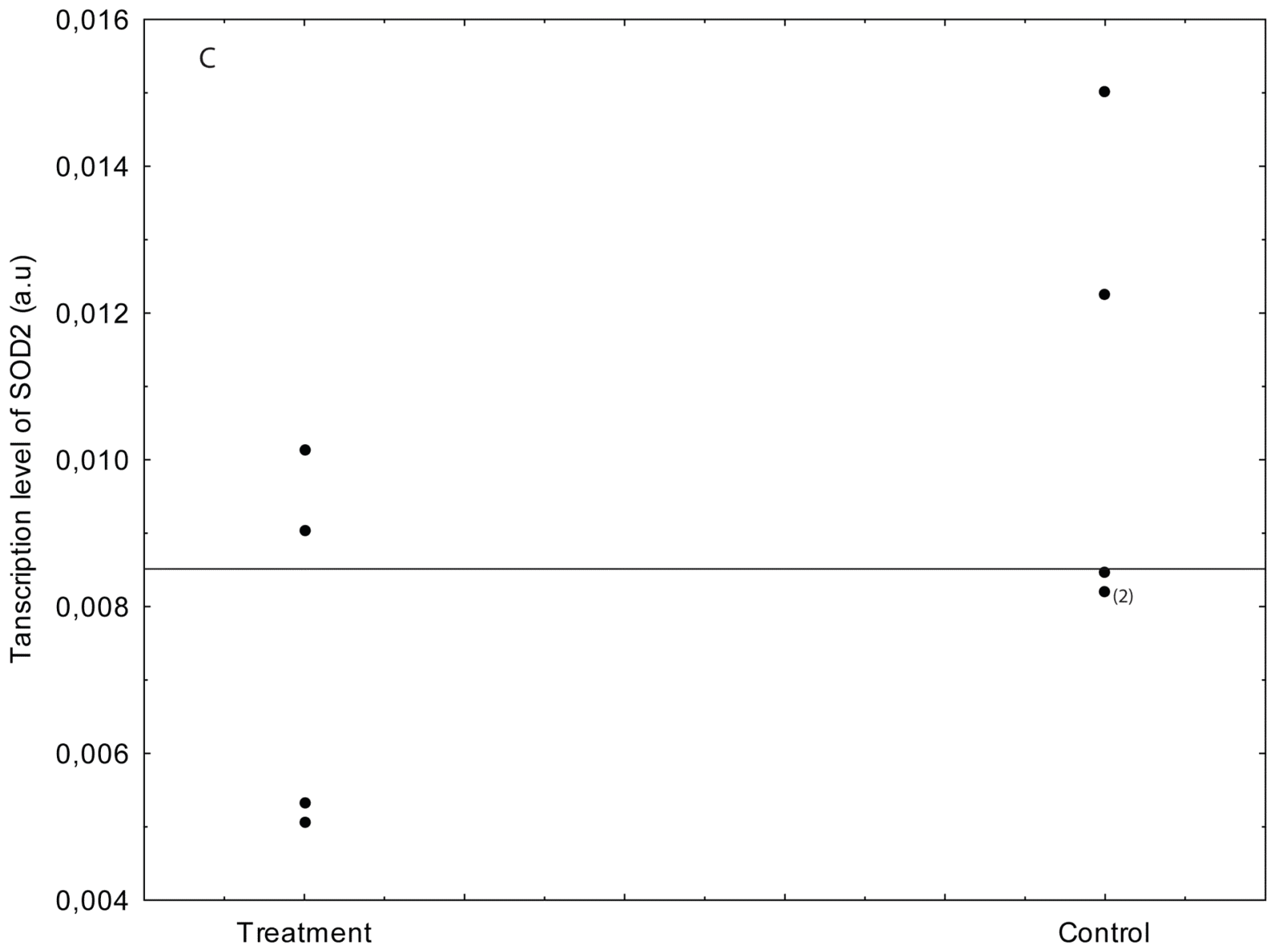

Fig. (2). Change in transcription levels (arbitrary units, a.u.) of the genes hsp70 (A), cco1 (B), sod2 (C) in response to heat treatment. $\mathrm{n}=5$ for the control group (CU) and $n=4$ for the heat treatment group (HU).

limits statistical analyses and interpretation, but was unavoidable under these exceptional experimental circumstances, which make this study unique.

\subsection{Gene Transcription Levels}

There was no difference in gene transcription level between the $\mathrm{CU}$ and the $\mathrm{HU}$ group for either $h s p 70$, ccol or mitochondrial sod2. This result is quite surprisingly since previous experimental investigations reported an upregulation of HSP70 in gills of the goby (Gillichthys mirabilis) or the common carp in response to heat stress at both the genetic and protein levels (temperature range: 18 to $32^{\circ} \mathrm{C}$ for goby and 20 to $28^{\circ} \mathrm{C}$ for carp; $\left.[14,15]\right)$. Heat shock proteins (HSPs) are molecular chaperone proteins that play a pivotal role in maintaining protein homeostasis during cellular exposure to proteotoxic stressors such as heat to prevent protein denaturation [15]. When protein homeostasis fails due to excessive stress, HSPs interact with stress denatured proteins, preventing their aggregation and/or degradation [16]. Thus, their expression levels are known to be up-regulated by heat stress $[14,17]$. Examination of data distribution (Fig. 2A) shows that the lack of statistical significance could be due to a low sample size. There was little overlap of values for the transcription level of hsp70 between CU and HU fish, with HU fish generally expressing higher transcription levels (Fig. 2A). However, one individual in the HU group exhib- ited a very low transcription level of $h s p 70$. While the three fish in the HU group with high values of $h s p 70$ transcription level displayed a normal up-regulation, one individual, in contrast, expressed lower transcription level than all CU fish, suggesting that this fish had exceeded its thermal tolerance. Thus, in addition to low sample size, an alternative hypothesis could be that animals can no longer adapt effectively to heat stress at the highest temperature used $\left(34.8^{\circ} \mathrm{C}\right)$. In contrast to $h s p 70$, there was a negative trend in the transcription levels of genes encoding for enzymes involved in aerobic metabolism (ccol) and defence against oxidative stress $(\operatorname{sod} 1)$. The transcription level of the two genes appears to be lower in the HU group compared to values in the CU group, as illustrated by data distribution (Fig. 2B and C). This trend of lower values in $\mathrm{HU}$ fish compared to the $\mathrm{CU}$ fish suggests a decrease in aerobic metabolism of heat-stressed fish. Interestingly, such a decrease in both $c c o-1$ and $\operatorname{sod} 2$ transcription levels was first reported in gills of eels exposed to hypoxia during a 14 day period $[18,19]$. Indeed, even though in our experiment we maintained oxygen levels to saturation, the increase in temperature decreased oxygen concentration from 9.4 to $6.9 \mathrm{mg} / \mathrm{L}$. Thus, in the present study, the response of both cco-1 and sod 2 in gills could be also associated to heat-induced hypoxia [18], suggesting that heatstressed carp suffer from impaired aerobic metabolism. This 


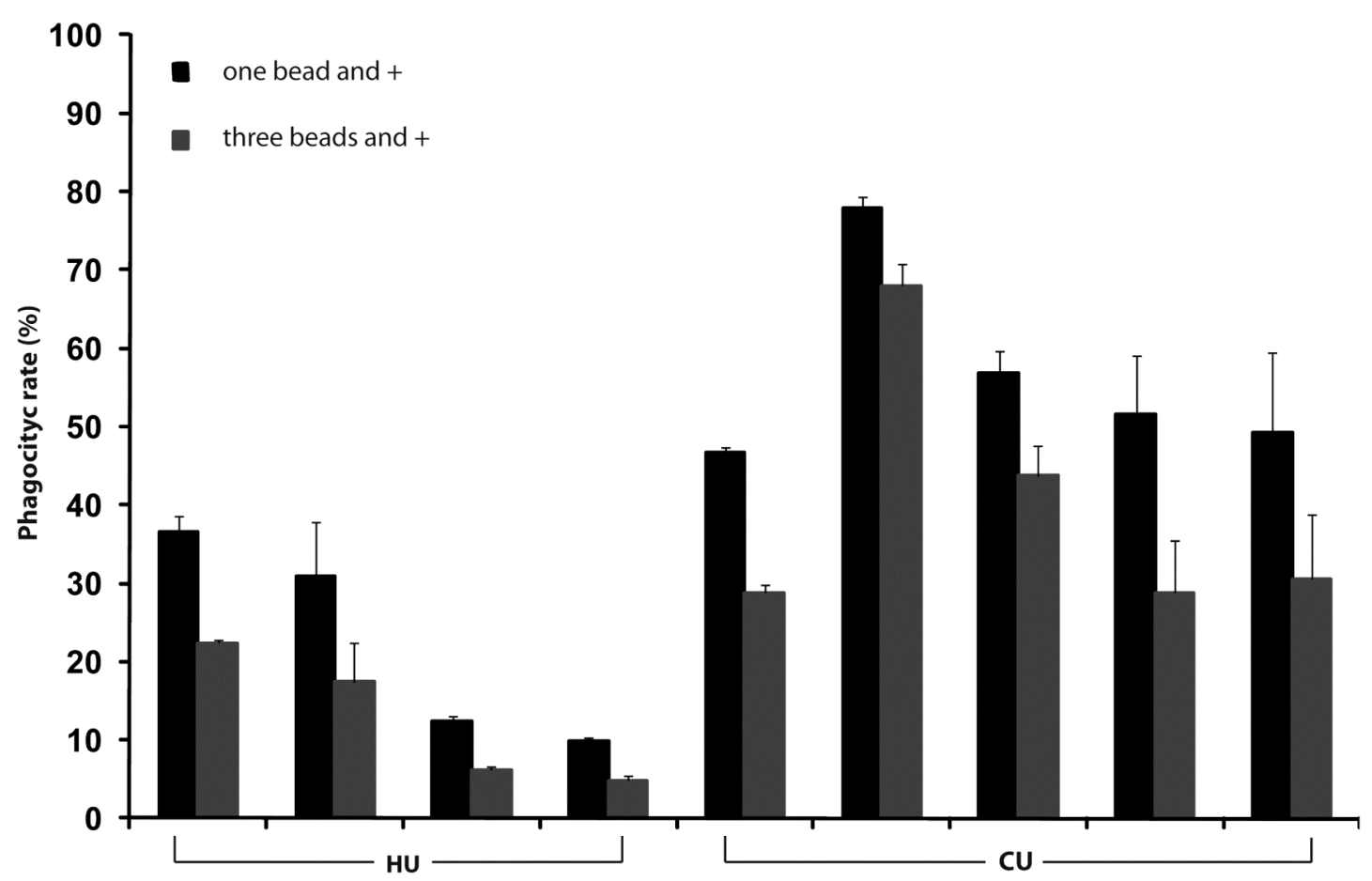

Fig. (3). Phagocytic rate (\%) of macrophages of fish in heat treatment unit (HU) where water temperature reached $34.8^{\circ} \mathrm{C}$; and fish in control unit $(\mathrm{CU})$ maintained at $18^{\circ} \mathrm{C}$, for one bead or more; and three beads or more. Data are shown as means + standard error ( $\mathrm{n}=5 \mathrm{for} \mathrm{CU}$; $\mathrm{n}=4$ for $\mathrm{HU})$. Each bar represents an individual ( $\mathrm{n}=9$ measurements per individual).

Table 2. Fish Behaviour Activities in Minutes (mean time \pm SD) in Control (CU) and Heat Treatment (HU) Unit at the Different Observations Time of the day and at Different Temperature. S is for Swimming, B for Breathing and $\mathrm{H}$ for Hiding/Resting

\begin{tabular}{|c|c|c|c|c|c|c|c|c|c|}
\hline & \multicolumn{9}{|c|}{ Water Temperature } \\
\hline & \multicolumn{3}{|c|}{$<33^{\circ} \mathrm{C}$} & \multicolumn{3}{|c|}{$33^{\circ} \mathrm{C}$ to $34.5^{\circ} \mathrm{C}$} & \multicolumn{3}{|c|}{$34.8^{\circ} \mathrm{C}$} \\
\hline $\mathrm{CU}$ & $\begin{array}{c}25^{\prime} \pm 0.5 \mathrm{~S} / \\
5^{\prime} \pm 0.3 \mathrm{~B}\end{array}$ & $\begin{array}{c}23^{\prime} \pm 0.4 \mathrm{H} / \\
7^{\prime} \pm 0.5 \mathrm{~S}^{*}\end{array}$ & $\begin{array}{c}24^{\prime} \pm 0.5 \mathrm{~S} / \\
6^{\prime} \pm 0.2 \mathrm{~B}\end{array}$ & $\begin{array}{c}26^{\prime} \pm 0.5 \mathrm{~S} / \\
4^{\prime} \pm 0.3 \mathrm{~B}\end{array}$ & $\begin{array}{c}25^{\prime} \pm 0.3 \mathrm{H} / \\
5^{\prime} \pm 0.4 \mathrm{~S}\end{array}$ & $\begin{array}{c}25^{\prime} \pm 0.4 \mathrm{~S} / \\
5^{\prime} \pm 0.2 \mathrm{~B}\end{array}$ & $\begin{array}{c}24^{\prime} \pm 0.4 \mathrm{~S} / \\
6^{\prime} \pm 0.4 \mathrm{~B}\end{array}$ & $\begin{array}{c}25^{\prime} \pm 0.7 \mathrm{H} / \\
5^{\prime} \pm 0.5 \mathrm{~S}\end{array}$ & $\begin{array}{c}25^{\prime} \pm 0.3 \mathrm{~S} / \\
5^{\prime} \pm 0.2 \mathrm{~B}\end{array}$ \\
\hline
\end{tabular}

"Note that during the hiding and swimming activity at this moment of the day, carp also did some breathing activity and there were not recorded as such because the fish make a quick up and down movement instead of staying at the water surface for at least 15 seconds.

appears moreover consistent with the behaviour of fish (see section 3.4).

\subsection{Phagocytosis}

Phagocytic rate was significantly lower in fish submitted to high water temperature in comparison to those kept at the control temperature (Fig. 3). For cells from pronephros cellular suspensions that phagocytized one or more beads $(\mathrm{p}<$ $0.05)$ and three or more beads $(\mathrm{p}<0.05)$, phagocytic activity was significantly lower $(39.7 \%)$ for fish submitted to elevated water temperature. This data brings direct support to the hypothesis that immunosuppression was a main cause of mortality in common carp exposed to very high water temperatures during summer 2001 in the St. Lawrence River [12].

\subsection{Fish Behaviour}

At their arrival, fish demonstrated a high level of stress, as indicated by repeated hitting of the tank walls. After five days, they appeared to have acclimated to laboratory conditions and began to swim normally. Their general behaviour also appeared similar to that observed in their natural environment, reducing swimming in the afternoon and hiding in the shaded part of the tank (about 25 minutes hiding and 5 minutes swimming) and increasing their swimming activity around dawn and dusk (swimming almost continuously during the 30 minutes observation time) (Table 2). At the end of the acclimation period, there was no notable difference in behaviour between carp in the two tanks. In contrast, when water temperature in the heat treatment tank reached $33^{\circ} \mathrm{C}$, carp spent more time near the surface compared to fish in the control unit (about 15 minutes versus 5 minutes over a 30 minutes observation period of swimming activity in $\mathrm{HU}$ and $\mathrm{CU}$ groups, respectively), although other behavioural end- 
points remained comparable. However, when water temperature reached $34.8^{\circ} \mathrm{C}$, fish in the heat treatment tank reduced their swimming activity considerably and alternated between staying at the surface and laying on the bottom (about 20 minutes at the surface and 10 minutes at the bottom) regardless of the time of the day. Meanwhile, carp in the control unit maintained their normal behaviour of spending most of the 30 minutes observation time in the evening swimming around the tank and reducing their activity during the afternoon. As prescribed by the protocol approved by our animal care committee, the experiment was stopped when these obvious signs of stress appeared. The last fish was sacrificed when water temperature reached $35.2^{\circ} \mathrm{C}$. Even though in our experiment we maintained oxygen levels to saturation, oxygen concentration decreased from 9.4 to $6.9 \mathrm{mg} / \mathrm{L}$. The lower oxygen concentrations were probably responsible for temperature-induced increased time spent at the surface. This experiment was carried out in controlled conditions, in contrast to the field situation. The conditions faced by carp during the summer 2001 were likely not as favourable as in the laboratory, even though the heat stress was similar, suggesting that carp were more vulnerable in the field to similar temperatures. For example, fish in the field have surely faced more severe hypoxia than in the laboratory and they were also exposed to different pathogens naturally present in the environment. This hypothesis is supported by studies reporting that fish are typically less tolerant to high temperatures in the field than in the laboratory [20-22]. In our study, carp began to show signs of distress at $34.8^{\circ} \mathrm{C}$. In 2001 , water temperature reached $34^{\circ} \mathrm{C}$ in some parts of the St. Lawrence River.

\section{CONCLUSION}

In this experiment, we tested experimentally the hypothesis that the elevated water temperatures encountered in the Saint-Lawrence River in the summer of 2001 were a sufficient source of stress to induce a depression of the immune system of these fish, which in turn could lead them to be more sensitive to bacterial infections by common freshwater bacteria. Fish submitted to high water temperatures expressed a significantly lower phagocytic rate than control fish, supporting the hypothesis that heat stress led to immunosupression. The transcription level of genes involved in the protection against heat, in aerobic metabolism and in combating oxidative stress was also investigated as additional indicators of heat stress. The patterns of genes transcription observed suggested a higher level of stress for heat-treated fish, but the low sample size prevented detection of significant differences.

During the fish kill, water temperature reached $34^{\circ} \mathrm{C}$ in some shallow water areas where carp were spawning, which is comparable to the upper limit of thermal tolerance found in this experiment $\left(34.8^{\circ} \mathrm{C}\right)$ where all parameters except water temperature were optimal. Our study supports the role of high water temperatures in the 2001 fish kill.

\section{CONFLICT OF INTEREST}

The authors confirm that this article content has no conflicts of interest.

\section{ACKNOWLEDGEMENTS}

The authors are indebted to Paul Messier, Jenny Guillemette, Geneviève Richard and Marc Létourneau for their hard work and skill for carp capture, as well as Philippe Brodeur, Nicolas Auclair and Remi Bacon for their field advice. Authors also want to give a special thanks to Marlène Fortier from Institute Armand Frappier (Michel Fournier's lab) for technical help and phagocytosis analyses and to Jean-Christophe Therrien and Serge Higgins from Université Laval for their expert advice and assistance in the husbandry of the carp.

This project was funded by Ministère des Ressources Naturelles et de la Faune to M.M and FQRNT to V.O.

\section{REFERENCES}

[1] Bergstedt R, Argyle RL, Seelye JG, Scribner KT, Curtis GL. In situ determination of the annual thermal habitat use by lake trout (Salvinus namaycush) in Lake Huron. J Great Lakes Res 2003; 29: $347-$ 61.

[2] Cooke SJ, Bunt CM, Schreer JF. Understanding fish behavior, distribution, and survival in thermal effluents using fixed telemetry arrays: A case study of smallmouth bass in a discharge canal during winter. Environ Manag 2004; 33:140-50.

[3] Mohseni O, Stefan HG, Eaton JG. Global warming and potential changes in fish habitat in U.S. Streams. Clim Change 2003; 59: 389-409.

[4] Sinokrot BA, Stefan HG, McCormick JH, Eaton JG. Modeling of climate change effects on stream, temperatures and fish habitats below dams and near groundwater inputs. Clim Change 1995; 30: 181-200.

[5] Brodeur P, Mingelbier M, Morin J. Impacts des variations hydrologiques sur les poissons des marais aménagés du Saint-Laurent fluvial. Nat Can 2004; 128: 66-77.

[6] Gillet C, Péquin P. Effect of temperature changes on the reproductive cycle of roach in Lake Geneva from 1983 to 2001. J Fish Biol 2006; 69: 518-34.

[7] Ham J, Toran L, Cruz J. Effect of upstream ponds on stream temperature. Environ Geol 2006; 50: 55-61

[8] Mingelbier M, Trencia G, Dumas R, et al. Avis scientifique concernant la mortalité massive des carpes dans le Saint-Laurent durant l'été 2001. Société de la faune et des parcs du Québec, M.d.1.e. Biodôme de Montréal, Environnement Canada (Ed.), Québec 2001.

[9] Mortsch LD, Quinn FH. Climate change scenarios for Great lake basin ecosystem studies. Lim Ocean 1996; 41: 903-11.

[10] Monette S, Dallaire AD, 'gelbier M, et al. Massive mortality of common carp (Cyprinus carpio carpio) in the St. Lawrence River in 2001: Diagnostic investigation and experimental induction of lymphocytic encephalitis. Vet Path 2006; 43: 302-10.

[11] Livak KJ, Schmittgen TD. Analysis of relative gene expression data using real-time quantitative PCR and the $2^{-\Delta \Delta C T}$. Methods 2001; 25: 402-8.

[12] Ouellet V, Mingelbier M, St-Hilaire A, Morin J. Frequency analysis as a tool for assessing adverse conditions during a massive fish kill in the St. Lawrence River, Canada. Wat Qual Res J Can 2011; 45: 47-57.

[13] Brousseau P, Payette Y, Blakley B, et al. Eds. Manual of Immunological Methods. Boston, USA: CRP Press 1998.

[14] Buckley BA, Gracey AY, Somero GN. The cellular response to heat stress in the goby Gillichthys mirabilis: a cDNA microarray and protein-level analysis. J Exp Biol 2006; 209: 2660-77.

[15] Wang Y, Xu J, Sheng L, Zheng Y. Field and laboratory investigations of the thermal influence on tissue-specific Hsp70 levels in common carp (Cyprinus carpio). Compar Biochem Physiol - Part A: Mol Int Phys 2007; 148: 821-7.

[16] Wirth D, Christians ES, Drion PV, Dessy-Doize C, Gustin P. Les protéines de choc thermique (heat shock proteins-Hsps). II. Hsp70 : biomarqueur et acteur du stress cellulaire. Ann Med Vet 2003; 147: 127-44. 
[17] Parsell DA, Lindquist S. The function of heat-shock proteins in stress tolerance: degradation and reactivation of damaged proteins. Ann Rev Gen 1993; 27: 437-9.

[18] Pierron F, Baudrimont M, Gonzalez P, Bourdineaud J-P, Elie P, Massabuau J-C. Common pattern of gene expression in response to hypoxia or cadmium in the gills of the European glass eel (Anguilla anguilla). Environ Sci Tech 2007; 41: 3005-11.

[19] Heise K, Puntarulo S, Nikinmaa M, Abele D, Portner HO.Oxidative stress during stressful heat exposure and recovery in the North Sea eelpout Zoarces viviparus L.J. Exp Biol 2006; 209: $353-63$.
[20] Beitinger TL, Bennett WA. Quantification of the role of acclimation temperature in temperature tolerance of fishes. Environ Biol Fishes 2000; 58: 277-88.

[21] Beitinger TL, Bennett WA, McCauley RW. Temperature tolerances of North American freshwater fishes exposed to dynamic changes in temperature. Environ Biol Fishes 2000; 58: 237-75

[22] Ineno T, Tsuchida S, Kanda M, Watabe S. Thermal tolerance of a rainbow trout Oncorhynchus mykiss strain selected by hightemperature breeding. Fish Sci 2005; 71: 767-75.

Received: September 09, 2013

Revised: October 25, 2013

Accepted: October 25, 2013

(C) Ouellet et al.; Licensee Bentham Open.

This is an open access article licensed under the terms of the Creative Commons Attribution Non-Commercial License (http://creativecommons.org/licenses/ by-nc/3.0/) which permits unrestricted, non-commercial use, distribution and reproduction in any medium, provided the work is properly cited. 